\title{
English Literary Materials to Ignite Students' Language Study-skill (Inspiration, Interactivity and Creativity)
}

\author{
Abdul Halim \\ English Department \\ Faculty of Languages and Literature \\ Universitas Negeri Makassar \\ Makassar, Indonesia
}

\begin{abstract}
The study was a developmental research and experimental ( $R \&$ D) model. The data were collected through (a) an English essay test involving different difficulty levels of questions (cognitive, analytic, evaluative and creative), and (b) classroom observation and interview. Results from this study identified that the learning processes and learning results clearly reflected the three language study skills.
\end{abstract}

Keywords—literary materials; formatting; language study skills

\section{INTRODUCTION}

There are so rarely course books which are specially designed for teaching English in junior high schools concocted from literary works that may be accessed easily. Most of the teachers tend to use published materials rather than authentic materials that are unknown whether the materials may largely stimulate the study skills like inspiration, interactivity and creativity or not, useful for English education in creating autonomous English learners. Therefore, "English Literature Based-Course Book" used in the classroom is expected to be inspirational thereby it initiates the students to be more interactive and creative.

A Study on a material development under a collaborative project by three similar universities in the USA has been done. The results indicated that the students tended to have a positive response to the material reflected in the questionnaires and classroom observations. The materials given to them could significantly increase the students' critical thinking and autonomous learning that are highly effective for language acquisition.

Many reading specialists claimed that an important missing element in the part of most learners is their capability to obtain the effective reading [1]. This most probably came to happen since the method of language instruction that the educators or teachers embrace.

Another viewpoint about attempting a good understanding of a text is related to the theory of proposition or ideas. A reader should improve his ability to discover ideas provided by a text and be able to establish or connect between related ideas in the text [2]. This kind of reading skill is highly related to the cognitive process in the brain. It is the process of linking to the new knowledge or something being learned, and the prior knowledge or something knew and understood. The rehearsal process in reading activity is extremely necessary for increasing the mental ability used for reading ranging from somewhat simple language to greater complicated paragraph or text [3]. The capability to connect the ideas in the reading means the capability to track the background knowledge and the new idea or information

\section{METHOD}

This research was designed to develop research [4]. It developed a teaching material taken from English literary works such as short story, tale, fable, anecdote and poem. The literary genre and theme were selected based on the students' interest as reflected in the questionnaire. 135 students of the third year class from four Junior High Schools were engaged in the questionnaire. By this way, the teaching material was expected to be inspirational since it could easily assist the students and express richly their ideas about the present topics. To stimulate interactivity and creativity, the questions after reading were designed to include not only the literal but also the high level questions like analyzed, evaluative and creative questions. In the implementation the researcher was assisted by four teachers who handled English Subject in each class while the researcher acted as an observer to notice and videotaped the ongoing classroom interaction on group work.

\section{RESULTS AND DISCUSSION}

\section{A. Results}

Before the video show, the pre-reading activity was conducted, and it was intended to open up the students' mind about the topic through pre-reading questions. Three questions were posed in this phase, and the students were expected to respond orally. The first question posed to students is "What skills does a frog have?" In fact, the students replied variously based on the students' experience or background knowledge.

After the video show, the class came to reading activity and then it was followed by some questions. They were arranged based on the thinking skills like cognitive, analysis 
and evaluative questions. There were three questions to be discussed in this phase. The first question was "In what ways are the prince and princess different?". The students replied the question in varied forms based on their reasons and comments.

The responses in this analytical question designate a binary apportion of how a human views the world. Commonly, the students often see the world in a contradictive idea or they viewed the point based on the distinctive perspectives. Male vs. female means different sexes; animal vs. human designated a distinctive type of creature; poor vs. rich was viewed from different social status; beautiful vs. disgusting was viewed from the physical trait. Differently, there was an answer given by some students "Handsome and beautiful". Basically it was a logical response since the students thought that a prince is commonly handsome even though he was being cursed as a frog, while a princess is beautiful. However the response did not indicate at all an opposite meaning. The students seemed to have a positive standing point in this account.

The next open question was "What do people usually do to escape from the power of enchantment?" It was only answered in three types of responses. This fact leads us to conclude that to break the power of enchantment can be through different ways ranging from radical action (killing the witch), to very religious and wise action (meeting an uztas and pray to God). The answers depict that the students had different perspectives to escape from the control of a witch based on their personal experience that they know about how to overcome the black magic.

The third question tends to explore more the students' experience about the real condition of a frog. The question is "Why do you think the prince was enchanted by the witch to be a frog rather than other animals?"

The students' answers depict that they could express their opinions in order to answer the questions. In other words they made use their prior knowledge to reply the creative questions. Some commented based on their reading experience; and some others seemed to use their visual experience. The face of a frog is disgusting because it is full of warts and its mouth is very wide. However, some of them also utilize their logical thinking by rejecting the fact that a frog may become a prince. These all could be expressed in English through a vividly interactive discussion in the class. They discussed the existing different ideas through two-ways communication or studentstudent communication. Sometimes they got involved in a discussion with the teacher to clarify the teacher' language instruction or the classroom task to be done by them.

An autonomous learner was assigned by the students could perform their individual assignment given in the process of learning. Performing the individual task is the final objective of all learning. The students were given the individual task like writing activity for example "write a letter of promise written by the princess to the frog that she would keep the promise after she got back her ball". Based on the data taken from the individual task, there were some types of promise written by the students.

\section{B. Discussion}

A good teaching material is a material that may take the students into a comfort zone where they feel happy rather than monotonous or too serious leading to the students' boredom. Differently, if the text can communicate with the students, they look interested, fascinated, enthusiastic and curious. They are eager to tackle all the tasks given by the teacher. The existing interaction between the text and the students greatly induces the good learning process. Such a condition is really expected to happen in the learning process.

The questions posed in the reading text require the students to think based on their own opinions. Through the high level questions the students would explore and elaborate the reasonable answers and then confirm it with other students through group discussion. The discussion is expected to inspire the students to the creative thinking. Under such a circumstance, new ideas will appear and then written in different responses based on their background knowledge or experience. Dillon (1994) states that discussion can be used to enhance the students' opportunity to get together in the learning process. The students can actively pose questions and get the answers through sharing ideas. They possibly talk about the topical issues, understand concepts of things and then go to the conclusion and judgment.

\section{CONCLUSION}

Based on the research results we lead to conclude that the content of an inspirational, interactive and creative course book must be relevant to the students' preferences like interest and need. An interactive condition happens when the reading material relates more or less to the students' background knowledge thereby they become motivated to perform their tasks from the teacher. Through high level question, the students got inspired to get their own ideas different from what in the text. They got free to write their own sentences, phrases and sentences and this circumstance assigns that the students become creative.

\section{REFERENCES}

[1] M. Shih, "Beyond comprehension exercises in the ESL academic reading class," Tesol Q., vol. 26, no. 2, pp. 289-318, 1992.

[2] T. A. Van Dijk, Some aspects of text grammars: A study in theoretical linguistics and poetics, vol. 63. Walter de Gruyter GmbH \& Co KG, 1972.

[3] B. K. Britton, "Understanding expository text: Building mental structures to induce insights.," 1994.

[4] L. R. Gay, G. E. Mills, and P. W. Airasian, Educational research: Competencies for analysis and applications. Pearson Higher Ed, 2011.

[5] J. T. Dillon, Using discussion in classrooms. Open University, 1994. 